\title{
Changes in the ground environment under the influence of fires in the territory of the State Natural Reserve «Olekminsky»
}

\author{
Svetlana Vershinina $^{1}$, Lyudmila Gabyshcheva ${ }^{2}$, Nikolay Tyutrin ${ }^{1 *}$, Vasily Verkhoturov ${ }^{3}$, and \\ Andrey Lagunov ${ }^{4}$ \\ ${ }^{1}$ Irkutsk national research technical University, Lermontova Str. 83, 664074, Irkutsk, Russia \\ ${ }^{2}$ State natural reserve «Olekminsky», Logovaya Str. 31, 678100, Olyokminsk, Sakha Republic, \\ Russia \\ ${ }^{3}$ Kaliningrad State Technical University, Sovietsky Prospect 1, 236022, Kaliningrad, Russia \\ ${ }^{4}$ Siberian Fire and Rescue Academy of the State Fire Service of the Emergencies Ministry of Russia, \\ Severnaya Str. 1, 662972, Zheleznogorsk, Krasnoyarsk Krai, Russia
}

\begin{abstract}
This paper discusses the chronology and cause of forest fires on the territory of the State Reserve "Olekminsky". Forest fires on the territory of the reserve are low-level, caused by dry thunderstorms. The overgrowth of burnt areas occurs at the expense of specific groups of pyrophyte plants. For 2-3 years after the fires, Camenerion angustifolium (L.) Scop., Corydalis sibirica (L.) Pers., Plantago canescens Adams, Crepis tectorum L. and others were found. In waterlogged areas, Tephroseris palustris (L.) Reichenb appear and subsequently do not occur, and mosses: Marshantia polymorpha L., Ceratodon purpureum (Hedw.) Brid. It was found that the restoration of ground cover is mainly due to species characteristic only for intermediate stages: Lichens - Baeomyces carneus, Dibaeis baeomyces and Trapeliopsis granulosa, as well as Arctous erythrocarpa (Small) M. Ivanova, Chamaenerion angustifolium (L.) Scop., Calamagrostis obtusata Trin, Carex spp., cereals and green mosses. More than 40 species of lichens participate in the formation of the ground cover of the studied larch forests, mainly bushy species of Cladonia, Stereocaulon, Peltigera. Forest fires of a natural nature occurring on the territory of the reserve are the main limiting factor affecting bio-resources and their restoration.
\end{abstract}

\section{Introduction}

Forest fires are an eternal companion of forests, which largely determines the modern appearance of forest cover in the vast territories of the taiga zone [1]. Especially great is the role of fires in plantations of light-coniferous tree species (pine trees, larch trees), which, due to their natural biological characteristics, are most susceptible to fire loads. Here, fires act as the leading, and sometimes the only forest-forming factor, which, depending on the nature of the fire impact, determines the degree of transformation of the environment, the

\footnotetext{
* Corresponding autor: tno73@yandex.ru
} 
composition and structure of forest communities, the direction, rate of recovery successions and the dynamics of renewable processes [2]. The value of the pyrogenic factor in the forest formation process increased in the second half of the XX century due to a sharp increase in the share of anthropogenic fires $[3,4]$. Note that in Central Yakutia, as in other regions, the main cause of fires is the human factor [5]. The role of fires in forest life is far from ambiguous in its consequences and ecological content [6]. On the one hand, fire in the forest is a destructive factor of destructive power, which acquires the character of ecological catastrophes in certain periods, and leads to partial or complete destabilization of the forest ecosystem. On the other hand, forest fires have a positive impact on the condition and development of forest stands, acting as a factor of renewal in the ecosystem and contributing to the natural renewal of tree species [7-10]. This is especially true for forest formations that are formed by tree species with a pyrogenic life strategy.

The Federal State Budgetary University State Nature Reserve "Olekminsky" is a nature protection, research and environmental education institution of federal significance, aimed at preserving and studying the natural course of natural processes and phenomena, the genetic fund of the plant and animal world, individual species and communities of plants and animals, typical and unique ecological systems. Any activity that contradicts the objectives of the reserve and the regime of special protection of its territory is prohibited on the entire territory of the reserve, so the territory of the reserve's forest fund is a classic model that allows us to study the causes of forest fires and damage caused by pyrogenic effects.

Due to the exceptional importance of forest fires in the modern dynamics of forest cover, it is necessary to have complete information about the dynamics of forest fires in various natural and geographical conditions. Of course, these data allow us to assess the degree of fire loads on forests, plan measures for economic use and care of plantings, carry out preventive work to prevent and eliminate fires, and can also serve as a basis for assessing the environmental consequences of forest fires and forecasting changes in the forest fund.

The purpose of this paper is to analyze the causes and chronology of fires on the territory of the reserve, as well as post-fire restoration of the ground cover.

\section{Methods and materials}

Fire dating was performed on the basis of satellite images, as well as analysis of cores or cuts taken on the territory of the test area with 5-10 live trees damaged by fire within a radius of 50-100 m. In addition, other signs were taken into account (the presence of coal layers in the litter, the maximum age of pine undergrowth, etc.). The degree of damage to the tree tier by the last fire was determined by the formula [11]. The ground cover was studied at sites $1 \times 1 \mathrm{~m}$, located at a distance of 5-7 m from each other. The 25 sites were described for each test area. The projection coverage (in \%) and height (in 5 dimensions) of moss-lichen layer species were determined at all sites [12].

\section{Discussion of the results}

State Nature Reserve "Olekminsky" is located to the South of the middle reaches of the Lena river. The reserve, located at the junction of the Aldan plateau and the Prilensky plateau in the taiga zone of the Republic, is located in a zone of continuous permafrost. In the southern part of the reserve, the heights reach 900-1100 meters, and as we move to the North, the heights decrease to about 700-800 meters. The variety of natural complexes allows us to consider the Olekminsky reserve as a standard of boreal forests in Southern 
Yakutia. All soils of the reserve area belong to the subtype of cold, long-frozen soils [13]. The reserve is located within the Central Siberian and Trans-Baikal provinces of Circumboreal floristic region and is a typical area of mountain taiga forests in the South of Yakutia, where there is different combination of all the main tree species typical for the forests of Southern Siberia. The territory is home to Pínus sibírica, Abies sibirica, Picea ábies, Pinus sylvestris and Bétula péndula. More than half of the forested area is occupied by stands Larix gmelinii, represented by both pure and mixed stands. Forests with a predominance of dark coniferous species are found in small areas, mostly confined to the bottoms of valleys of streams and rivers. On the territory of the reserve, the VerkhneAmginsky tundra-sparsely wooded loach district is allocated. Here, the upper border of the forest (more than $900 \mathrm{~m}$ above sea level) is represented by sparsely wooded areas, which are replaced by spruce and cedar.

The forest fund is dominated by larch $(54.5 \%)$, pine $(23.1 \%)$, birch $(5.5 \%)$ and cedar $(1.3 \%)$ stands. Forest fires on the territory of the reserve are usually low-level, which is due to the different age of larch plantations and their multi-tiered nature. Renewal of the forest after a fire in such conditions occurs without changing the species.

It is known that Northern taiga larch ecosystems have pulsed pyrogenic stability and are able to maintain their structure and functions, as well as recover after sharp disturbances caused by fire [14]. Data on the burning capacity of the reserve's forest fund over the past ten years show that dry thunderstorms play a major role in the occurrence of forest fires [15]. So, in 2002, 9 fires were registered, $2007-1,2008-12,2009-1$ and 2011-4.

The forest area of the reserve is 757169 ha, which is $89.38 \%$ of the total area. During the 27 years of the reserve's existence, more than 46278.3 hectares of forest were exposed to fires, which is more than $50 \%$ of the reserve's territory (figure 1). During this time, 57 forest fires were registered. The largest fires were observed in 1990, 2002, 2008 and 2011.

The overgrowth of burnt areas occurs at the expense of specific groups of pyrophyte plants. For 2-3 years after the fires, Camenerion angustifolium (L.) Scop., Corydalis sibirica (L.) Pers., Plantago canescens Adams, Crepis tectorum L. and others were found. In waterlogged areas, Tephroseris palustris (L.) Reichenb appear and subsequently do not occur, and mosses: Marshantia polymorpha L., Ceratodon purpureum (Hedw.) Brid.

It was found that the restoration of ground cover is mainly due to species characteristic only for intermediate stages: Lichens - Baeomyces carneus, Dibaeis baeomyces and Trapeliopsis granulosa, as well as Arctous erythrocarpa (Small) M. Ivanova, Chamaenerion angustifolium (L.) Scop., Calamagrostis obtusata Trin, Carex spp., cereals and green mosses.

The restoration of ground cover in areas with different fire ages was studied. More than 40 species of lichens participate in the formation of the ground cover of the studied larch forests, mainly bushy species of Cladonia, Stereocaulon, Peltigera, whose contribution to the total coverage is up to $80-85 \%$. Other lichens are represented in smaller numbers: Cetraria laevigata Rassad, Cetraria islanduca (L.) Ach., Flavocetraria cucculata (Bellaedi) Kärnef. et Thell, Nephroma arcticum (L.) Torss and others. In general, the species composition of lichens, here, on burnt areas, is significantly depleted and represented mainly by a small number of tubular and awl-shaped species of Cladonia (table 1).

Natural features of the region - a combination of permafrost with a lack of atmospheric moisture and a dry climate - caused the creation of natural causes for the occurrence and spread of forest fires. Economic development of the region plays an important role in the forest formation process of the forests of Yakutia. The role of humans in the occurrence and spread of forest fires has been particularly growing in recent years. Yakutia, in comparison with other regions, has for a long time been characterized by a particularly high level of forest burning, which is due not only to arid conditions and a large population density, but 
also to the direction of agriculture in these areas. Fire clearing of meadows, pastures and hayfields was the main cause of forest fires until recently. In Yakutia, forest ecosystems of the cryolithozone are exposed to the destabilizing effects of fires at least 3-5 or more times during the life of a single generation of stands. There is practically no forest area that has not been affected by pyrogenic activity at one time or another. Therefore, modern forests represent certain stages of post-fire recovery successions. The reserve can be considered as a model for studying pyrogenic succession.

Table 1. Species diversity of lichens on burnt areas and indigenous communities

\begin{tabular}{|l|l|}
\hline Burnt area $\mathbf{1 0}$-15 years & $\begin{array}{l}\text { Cedar-elm-pine-larch mixed-grass-white-moss } \\
\text { forest (25 species) }\end{array}$ \\
\hline Baeomyces carneus Floerke & Cetraria islandica (L.) Ach. \\
Cladonia amauracraea (Floerke) Schaer & Cladonia amauracraea (Floerke) Schaer \\
Cladonia botrytes (Hagen.) Willd. & Cladonia arbuscula ssp. mitis (Sandst.) Ruoss \\
Cladonia cervicornis ssp. verticillata (Hoffm.) & Cladonia bacillaris (Ach) Nyl. \\
Ahti & Cladonia botrytes (Hagen.) Willd. \\
Cladonia coccifera (L.) Willd. & Cladonia cervicornis ssp. verticillata (Hoffm.) \\
Cladonia cornuta (L.) Hoffm. & Ahti \\
Cladonia gracilis (L.) Willd. & Cladonia coccifera (L.) Willd. \\
Dibaeis baeomyces (L. fil.) Rambold et Hertel & Cladonia cornuta (L.) Hoffm. \\
Trapeliopsis granulosa (Hoffm.) Lumbsch. & Cladonia digitata (L.) Hoffm. \\
& Cladonia ecmocyne (Ach.) Nyl. \\
& Cladonia fimbriata (L.) Fr. \\
& Cladonia gracilis (L.) Willd. \\
& Cladonia humilis (With.) Laundon \\
& Cladonia macroceras (Delise) Ahti \\
& Cladonia pyxidata (L.) Hoffm. \\
& Cladonia rangiferina (L.) Weber. et Wigg. \\
& Cladonia stellaris (Opiz) Pouzar et Vezda \\
& Peltigera aphthosa (L.) Willd. \\
& Peltigera canina (L.) Willd. \\
& Peltigera didactyla (With.) J. R. Loundon \\
Peltigera elisabetae Gyeln. \\
Peltigera leucophlebia (Nyl.) Gyeln. \\
Peltigera malacea (Ach.) Funck. \\
Peltigera membranacea (Ach.) Nyl. \\
& Stereocaulon glareosum (Savitz) H. Magn. \\
Stereocaulon paschale (L.) Hoffm. \\
\hline
\end{tabular}

Table 2. Similarity of the species composition on burnt areas during the succession by the Sorensen coefficient.

\begin{tabular}{|c|c|c|c|c|}
\hline $\begin{array}{c}\text { Age of the burnt area, } \\
\text { years }\end{array}$ & $5-10$ & $30-40$ & $60-70$ & More than 70 \\
\hline Up to 3 years & 0.28 & 0.30 & 0.25 & 0.20 \\
\hline $5-10$ & - & 0.35 & 0.41 & 0.34 \\
\hline $30-40$ & - & - & 0.65 & 0.68 \\
\hline $60-70$ & - & - & - & 0.76 \\
\hline
\end{tabular}


The degree of fire danger in the forests of Yakutia is currently determined by the unified all-Russian scale. This scale is uniform for the entire territory of Russia and does not take into account local natural and climatic features, so the development and application of local scales is of great practical importance. Analysis of the degree of similarity and differences in species composition showed the least similarity between the burnt areas of early and later succession, which indicates the presence of a specific pyrogenic complex of species. Complexes of species of later stages of restoration and indigenous communities have the greatest similarity (table 2).

In the forest zone, the formation of vegetation cover is to some extent due to the influence of fires. Destroying the moss and grass cover, burning the litter and humus, fire creates favorable conditions for the germination of seeds of a number of plants, the appearance and formation of self-seeding pine, birch and some other tree species. At the same time, destroying the undergrowth of trees, fire often contributes to the appearance of low-value species and leads to the loss of economically valuable species. Forest fires not only affect the composition of the forest stand, changing the type of forest, but also disrupt its age structure. Even crown fires, causing injuries to trees, weaken them and contribute to the formation of windfall and windbreak, loss of old-aged (mother) individuals of the dominant species from the stand. In the course of our research, we observed changes in the species richness and the ratio of higher vegetation and lichens at different stages of succession (figure 1). The settlement of burnt areas with new species is finished by 20-25 years and then there is a decrease in the species diversity of vascular plants and mosses.

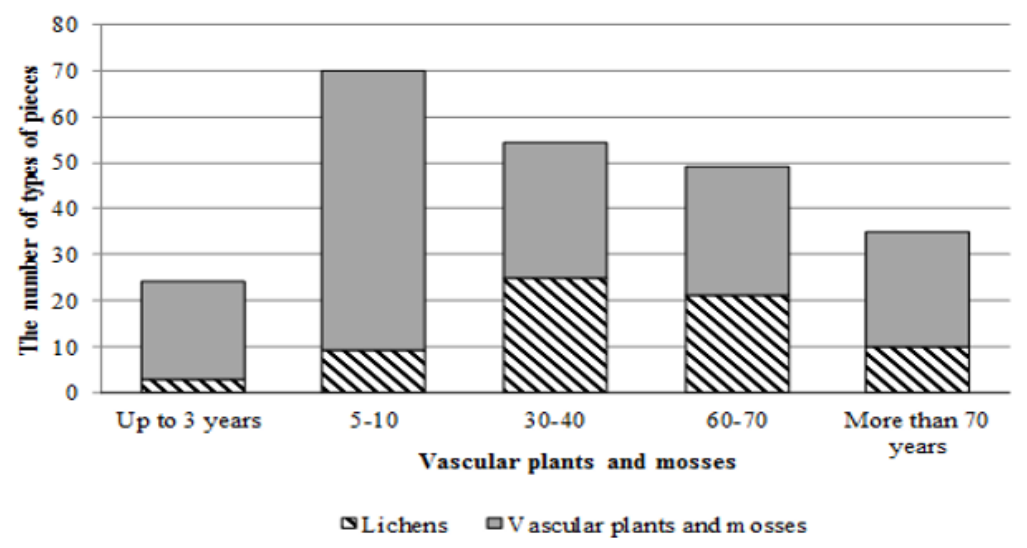

Fig. 1. Changes in species richness at different stages of succession on burnt areas.

\section{Conclusions}

The restoration of indigenous plant communities occurs from the age of 20-25 years, which generally confirms the general trend of successional series in the cryolithozone of Central Yakutia [8-10]. Restoration of ground moss-lichen and lichen cover in such conditions requires considerable time and occurs only on poor gravelly and sandy loam soils.

In dry years, the proportion of stands exposed to fire reaches $36.9 \%$ of the total area covered by forest vegetation. On average, 2 forest fires occur annually with an area of 46278.3 ha and an average area of 811.9 ha per fire. Thus, almost all the vegetation of the reserve was formed under the influence of forest fires. The reserve is characterized by a gradual increase in the number of forest fires while reducing the area covered by them. There is a need to improve the system of organization of forest protection from fires, and especially in the territories experiencing the highest degree of pyrogenic load. Zoning the 
territory of the reserve for fire danger will allow developing a set of measures aimed at preventing the occurrence and limiting the spread of fires of vegetation, taking into account the regional characteristics of the territories.

\section{References}

1. S.M. Govorushko, Problems of regional ecology, 5, 9-5 (2009)

2. V.V. Furyaev, The role of fires in the process of forest formation (Nauka, Novosibirsk, 1996)

3. V.A. Nemkov, E.V. Sapiga, Ecology, 2, 141-147 (2010)

4. V.A. Kolbin, Ecology, 6, 420-426 (2008)

5. L.P. Lytkina, V.V. Protopopova, Forest fires as an ecological factor in the formation of forests in Central Yakutia. //Nauka and obrazovanie, 2, 13-15 (2006)

6. S.N. Sannikov, A.I. Zakharov, L.G. Smolnikova, N.S. Sannikova, Ecology, 1, 3-8 (2010)

7. V.V. Furyaev, V.I. Zablotsky, V.A. Chernykh, Fire resistance of pine forests (Nauka, Novosibirsk, 2005)

8. L.P. Lytkina, Ecology, 2, 168-173 (2009)

9. L.P. Lytkina, Bulletin of the Yakut State University, 6(1), 22-25 (2009)

10. L.P. Lytkina, Problems of regional ecology, 2, 66-66 (2009)

11. V.V. Gorshkov, N.I. Stavrova, Botanicheskiy journal, 2(87), 62-76 (2002)

12. V.V. Gorshkov, Ecology, 3, 179-183 (1995)

13. A.K. Konorovsky, Zoning and permafrost of the soils of Yakutia (Yakutsk, 1990)

14. P.A. Tsvetkov, Pyrogenic properties of Larix gmelinii, in the Northern taiga of Central Siberia (Krasnoyarsk, 2005)

15. V.I. Kozlov, V. A. Mullayarov, V. S. Soloviev, Modern problems of remote sensing of the Earth from space, 6(2), 388-393 (2009) 